\title{
Inhibition of HIV-1 Reverse Transcriptase of Selected Indonesia Medicinal Plants and Isolation of the Inhibitor from Erythrina variegata $L$. Leaves
}

\author{
Alvi Kusuma Wardani' ${ }^{1}$, Abdul Mun'im ${ }^{1}$, Arry Yanuar ${ }^{2}$ \\ 'Department of Pharmacognosy-Phytochemistry, Faculty of Pharmacy, Universitas Indonesia, Depok, West Java, INDONESIA. \\ 2Department of Biomedical Computation-Drug Design, Faculty of Pharmacy, Universitas Indonesia, Depok, West Java, INDONESIA.
}

\begin{abstract}
Objective: This research was conducted to screen inhibition of HIV-1 reverse transcriptase activity of selected Indonesia medicinal plants and to isolate HIV-1 reverse transcriptase inhibitor from Erythrina variegata leaves. Method: Screening inhibition of HIV-1 RT activity of selected Indonesia medicinal plants and isolated compounds were performed using HIV-1 RT colorimetric assay. The isolation of HIV-1 reverse transcriptase inhibitor was conducted using chromatography technique. The isolated compound was determined based on the data of UV, IR spectrophotometry, MS, 1D and 2D NMR spectroscopy. Results: Beside that, in vitro study of the leaves methanolic extract exhibited inhibition against HIV-1 RT activity with percent inhibition of $97.64 \%$ at concentration of $5 \mathrm{mg} / \mathrm{mL}$. Ethyl acetate fraction from the extract showed the strongest HIV-1 RT inbitory activity with $\mathrm{IC}_{50}$ of $429.28 \mu \mathrm{g} / \mathrm{mL}$. Isolation the HIV-1 RT inhibitor from the fraction give compound 1. Conclusion: Erythrina variegata leave extract ex-
\end{abstract}

hibited potent inhibition on HIV-1 RT activity. The isolated compound from the leaves was determined as apigenin-7-O- $\beta$-D-glucopyranoside and demonstrated HIV-1 RT inhibitory activity with the $\mathrm{IC}_{50}$ value of $100.59 \mu \mathrm{g} / \mathrm{mL}$.

Key words: Erythrina variegata, Flavonoid, HIV-1 RT, in vitro.

Correspondence:

Arry Yanuar, Department of Biomedical Computation-Drug Design, Faculty of Pharmacy, Universitas Indonesia, Depok 16424, West Java, INDONESIA.

Phone: +62 2178849001 , Fax:+62 217863433

Email: arry.yanuar@ui.ac.id

DOI: 10.5530/jyp.2018.10.38

\section{INTRODUCTION}

Human immunodeficiency virus (HIV) is the virus that can lead to HIV infection. During HIV infection, the virus attacks and destroys CD4 cells that cause a disruption in the immune system in the body to fight infection. Acquired immunodeficiency syndrome (AIDS) is the final stage of HIV infection that causes decreased immunity. ${ }^{1}$ Based on the report from UNAIDS, globally about 34 million people have been infected of HIV by 2011. It is estimated that $0.8 \%$ of people worldwide were aged $15-49$ years HIV infected. Asia has a number of nearly 5 million people living with HIV are spread in South Asia, Southeast Asia and East Asia. ${ }^{2} \mathrm{HIV}-1$ reverse transcriptase (RT) is a DNA-dependent polymerase that served as the catalyst of the synthesis of double-stranded DNA copies of HIV-RNA. This enzyme is an essential component of the life cycle of HIV-1 and as a target for anti-HIV therapy. drug therapy for HIV infection currently include inhibitors of RT and protease enzymes. ${ }^{3}$ Natural products, especially derived from plants, have been known as a source of anti-HIV drugs. Some of them showed inhibitory activity against a variety of processes in HIV-1 infection. ${ }^{4}$ Some plants have been known to benefit as an anti-HIV-1 from different countries. Syahdi et al. (2012) have performed virtual screening of HIV-1 transcriptase inhibitor base on Indonesian herbal database. ${ }^{5}$ The study resulted in top ten compounds which have the prospect to be developed as HIV-1 reverse transcriptase inhibitor. Based on that study, we selected ten plants which contained the compounds and evaluated their inhibitory activity in vitro against HIV-1 reverse transcriptase. The extract demonstrated the strongest HIV-1 RT inhibitory activity was further fractionated for isolation of the HIV-1 RT inhibitor.

\section{METHODS}

\section{Plant collection}

Plants were collected from Ministry of Health Garden in Citereup, West Java, Indonesia, and were authenticated by Indonesia Institute of Sciences, Cibinong, West Java, Indonesia. The voucher specimens were deposited in Herbarium and Pharmacognosy Laboratory, Universitas Indonesia.

\section{Extracts preparation}

Samples powder were macerated using $50 \%$ methanol, then filtered. The same procedure was repeated two times. Organic solvents were combined, and the evaporated under pressures at $50^{\circ} \mathrm{C}$ to give extracts. The methanolic extracts were dissolved using 10\% DMSO to generate sample solution for assay at $5 \mathrm{mg} / \mathrm{mL}$. Lamivudine was used as a standard assay due to lamivudine is antiretroviral from NRTI class. Lamivudine was dissolved using 10\% DMSO solvent to obtain standard concentration of lamivudine at $200 \mathrm{ppm}$.

\section{Extraction and Partition}

The dried leaves powder of Erythrina variegata was macerated using methanol. Methanolic extracts were evaporated in a rotary vacuum evaporator at $50^{\circ} \mathrm{C}$. The extract was dispersed in hot water and then partitioned with n-hexane, ethyl acetate, subsequently. Organic layers were evaporated under pressure to give hexane and ethyl acetate extracts. The aqueous layer was dissolved in methanol. The dissolved methanol was evaporated to give methanol fraction.

\section{Isolation}

Isolation was conducted using column chromatography and preparative thin layer chromatography (TLC). Ethyl acetate fraction was fractionated 
by column chromatography $(3 \times 50 \mathrm{~cm})$ using silica gel 60 as a stationary phase, a mobile phase of $\mathrm{n}$-hexane and ethyl acetate in gradient polarity system. The fractions were chromatographed using preparative TLC, and further purification was conducted by recrystallization. The isolated compound was identified to determine the chemical structure. Elucidation of the structure was performed by analyzing the spectral data of UV-Vis, MS, IR, ${ }^{1} \mathrm{H}-\mathrm{NMR},{ }^{13} \mathrm{C}-\mathrm{NMR}, 2 \mathrm{D}-\mathrm{NMR}, \mathrm{HMQC}$, and HMBC.

\section{HIV-1 Reverse Transcriptase (RT) Inhibitory Assay}

HIV-1 reverse transcriptase (RT) inhibitory assay was designed to be used in research studies as a method for the quantitative determination of RT activity in cell culture and other biological samples. This assay was used to determine the spread of retroviruses in mammalian cell culture infected. Reverse Transcriptase colorimetric kit assay was obtained from Roche, Germany. This assay was also used as a method of in vitro screening for RT inhibitor compounds. In this assay, lamivudine was used as positive control. ${ }^{6}$ The first step, HIV-1 Reverse Transcriptase (HIV-1 RT) enzyme recombinant $(0.2 \mathrm{ng} / \mu \mathrm{L})$ were placed to a microplate. The inhibitor dissolved in lysis buffer and the template were added into a microplate containing (HIV-1 RT) enzyme. Lysis buffer without the enzyme used as a blank control. Then a microplate incubated for $1 \mathrm{~h}$ at $37^{\circ} \mathrm{C}$. The solution cleaned and washed with washing buffer five times at a temperature of $15-25^{\circ} \mathrm{C}$. Washing buffer then removed carefully. After the microplate clean, anti-DIG-POD $(200 \mathrm{U} / \mathrm{mL})$ was added on each microplate and then covered with plastic back cover and incubated for $1 \mathrm{~h}$ at $37^{\circ} \mathrm{C}$. Once clean, ABTS substrate solution was added into each microplate and incubated for 10-30 minutes with a rotation of $250 \mathrm{rpm}$ at a temperature of $15-25^{\circ} \mathrm{C}$ until the color changes to green. Measurements carried out on a sample absorbance at $\lambda 405 \mathrm{~nm}$.

\section{RESULTS}

Table 1 shows HIV-1 RT inhibition activity of the extracts from selected medicinal plants. There are five plants that have inhibitory activity with a value of more than $90 \%$ inhibition including Erythrina variegata, Garcinia mangostana, Morus alba, Psidium guajava and Pluchea indica. Erythrina variegata has an inhibitory activity of $97.64 \%$. Inhibitory activity of HIV-1 RT by Erythrina variegata made possible by the erycristagallin content. ${ }^{6}$ Garcinia mangostana has a high activity in the inhibition of HIV-1 RT that is $98.01 \%$.

Table 2 shows the yield of each fraction from E. variegata leaves extract. Ethyl acetate fraction was further fractionated and gave precipitate. After purification, the isolate then separate using thin layer chromatography with ethyl acetate:n-hexane:chloroform $(4: 1: 1)$ as eluent. Isolated compound was a yellowish-white powder. The spot of the isolated compound on the plate chromatography showed bright yellow spot under UV light when sprayed with the $\mathrm{AlCl}_{3}$ color developer reagent. This is specific for flavonoid. $\mathrm{UV}_{\max }: 275$ and $355 \mathrm{~nm}$. MS spectra: $\mathrm{m} / \mathrm{z}$ $432.1840\left[\mathrm{M}^{+}\right]$. FT-IR $v_{\max }\left(\mathrm{cm}^{-1}\right): 3237,2930,1741,1178$ and $819 \mathrm{~cm}^{-1}$. Table 3 shows data of NMR spectra of the isolated compound.

Reverse transcriptase inhibitory activity carried out by using a kit of HIV-1 RT enzyme (Roche, Germany) using lamivudine as a positive control. HIV-1 RT Inhibitory activity assay was preceded by testing of Erythrina variegata isolate with lamivudine as standard at concentration range of $500 \mathrm{ppm}, 400 \mathrm{ppm}, 300 \mathrm{ppm}, 200 \mathrm{ppm}, 100 \mathrm{ppm}$.

Figure $2 \mathrm{~A}$ shows a value of $50 \%$ inhibitory concentration $\left(\mathrm{IC}_{50}\right)$ of lamivudine was $128.86 \mu \mathrm{g} / \mathrm{mL}$. According to data from lamivudine $\left(\right.$ Epivir $\left.^{\oplus}\right)$ assay, the lamivudine $\mathrm{IC}_{50}$ value of in vitro testing is in the range of $2 \mathrm{nM}$ to $15 \mu \mathrm{M}$. The Figure $2 \mathrm{~B}$ shows $\mathrm{IC}_{50}$ inhibition of HIV-1 RT enzyme by the isolate is $100.59 \mu \mathrm{g} / \mathrm{mL}$. From the $\mathrm{IC}_{50}$ value, it is known that isolate has higher activity compared to lamivudine as positive control.

\begin{tabular}{ccc}
\multicolumn{3}{l}{ Table 1: HIV-1 RT inhibition ratio of each extract } \\
\hline Samples (5 mg/mL) & Part of plants & Inhibition ratio (\%) \\
\hline Morus alba & Leaves & 98.45 \\
Garcinia mangostana & Leaves & 98.01 \\
Erythrina variegata & Leaves & 97.64 \\
Psidium guajava & Leaves & 97.21 \\
Plucea indica & Leaves & 94.37 \\
Vitex trifolia & Leaves & 86.98 \\
Foeniculum vulgare & Seeds & 84.73 \\
Erythrina cristagalli & Leaves & 76.65 \\
Theobroma cacao & Seeds & 69.57 \\
Strychnos lucida & Stems & 51.88 \\
Cinchona ledgeriana & Barks & 47.76 \\
Tinospora rumpii & Stems & 31.12 \\
Mangifera indica & Leaves & 26.64 \\
Artocarpus heterophyllus & Stems & 24.83 \\
Hibiscus mutabilis & Leaves & 11.09 \\
Lamivudine 200 ppm & & 98.45 \\
\hline
\end{tabular}

\begin{tabular}{cc} 
Table 2: Partitioned fractions of $\boldsymbol{E}$. variegata leaves extract \\
\hline Fractions & Weight $\mathbf{( g )}$ \\
\hline n-hexane & 142 \\
Ethyl acetate & 36 \\
Methanol & 90 \\
\hline
\end{tabular}

\section{DISCUSSION}

Some studies reported natural products inhibited HIV-1 RT activity. Garcinia mangostana inhibit the enzyme by the content of $\alpha$-mangostin, $\beta$-mangostin and $\gamma$-mangostin. According to the research conducted by Chin and Kinghorn 2008, $\beta$-mangostin showed inhibitory activity against HIV-1 RT of $42 \% .^{7}$ Morus alba has an inhibitory activity of $98.45 \%$ by the morusin content. Psidium guajava has the inhibitory activity of $97.21 \%$ associated with the content of quercetin and guajiverin. While Pluchea indica has an inhibitory activity of $94.37 \%$ due to plucheoside A content. ${ }^{6}$

Erythrina variegata L. (Fabaceae) grows in tropical regions such as Indonesia. The leaves were used as traditional medicine to treat pathogenic parasites and reduces the joint pain in India, China, and Southeast Asia. Erycristagallin isolated from the leaves showed antimicrobial activity against methicillin-resistant Staphylococcus aureus. The methanolic extract of leaves showed significant antinociceptive activity on writhing response in acetic acid induced., 5 There is no report about the antiHIV-1 RT activity of E. variegata.

The structure of isolated compound from E. variegata leaves was elucidated based on spectral data. The isolated compound was suggested as flavonoid due to the TLC chromatogram after was sprayed with $\mathrm{AlCl}_{3}$ solution. $\mathrm{AlCl}_{3}$ formed complex with hydroxyl groups and neighboring ketone (C-4 in ring $\mathrm{C}$ and $\mathrm{C}-5$ on ring $\mathrm{A}) .^{7}$ This result was supported by UV-Vis spectrum. ${ }^{8}$ The UV spectrum formed two bands on $\lambda 355$ and $275 \mathrm{~nm}$ which can be deduced that the isolate was flavonoid. The UV spectrum obtained was similar to the structure of flavones. ${ }^{9}$ The MS spectra showed the peak ion fragment at $\mathrm{m} / \mathrm{z} 432.1840\left[\mathrm{M}^{+}\right]$which 


\begin{tabular}{|c|c|c|c|c|}
\hline Position & $\delta C \mathrm{ppm}$ & $\delta H \mathrm{ppm}$ & HSQC & HMBC \\
\hline 2 & $121.0, s$ & - & $-\mathrm{C}-$ & - \\
\hline 3 & $99.6, s$ & $6.47, s$ & $-\mathrm{CH}-$ & - \\
\hline 4 & $180.5, s$ & - & $-\mathrm{C}-$ & - \\
\hline 9 & $106.1, s$ & - & $-\mathrm{C}-$ & - \\
\hline 5 & $163.0, s$ & - & $-\mathrm{C}-$ & - \\
\hline 6 & $94.5, d$ & $6.71(d, J=2 \mathrm{~Hz})$ & $-\mathrm{CH}-$ & - \\
\hline 7 & $161.6, s$ & - & $-\mathrm{C}-$ & - \\
\hline 8 & $94.5, d$ & $6.72(d, J=2 \mathrm{~Hz})$ & $-\mathrm{CH}-$ & C-9, C-10, C-5 \\
\hline 10 & $157.2, s$ & - & $-\mathrm{C}-$ & - \\
\hline $1^{\prime}$ & $122.6, s$ & - & $-\mathrm{C}-$ & - \\
\hline $2^{\prime}$ & $130.2, d$ & $7.39(d, J=8.5 \mathrm{~Hz})$ & $-\mathrm{CH}-$ & C-2, C-2 \\
\hline $3^{\prime}$ & $115.1, d$ & $6.82(d, J=8.5 \mathrm{~Hz})$ & $-\mathrm{CH}-$ & C-1', C-3' \\
\hline $4^{\prime}$ & $154.6, s$ & - & $-\mathrm{C}-$ & - \\
\hline 5 & $115.1, d$ & $6,88(d, J=8.5 \mathrm{~Hz})$ & $-\mathrm{CH}-$ & C-1', C-3' \\
\hline $6^{\prime}$ & $130.2, d$ & $7.40(d, J=8.5 \mathrm{~Hz})$ & $-\mathrm{CH}-$ & $C-2, C-2$ \\
\hline $1 "$ & $99.9, d$ & $5.06(d, J=7.0 \mathrm{~Hz})$ & $-\mathrm{CH}-$ & $\mathrm{C}-7$ \\
\hline $2 "$ & $77.2, d$ & 3.451 & $-\mathrm{CH}-$ & - \\
\hline $3 "$ & $73.1, d$ & 3.263 & $-\mathrm{CH}-$ & - \\
\hline $4 "$ & $69.6, d$ & 3.168 & -CH- & - \\
\hline $5 ”$ & $76.4, d$ & 3.278 & $-\mathrm{CH}-$ & - \\
\hline $6 "$ & $67.4, t$ & $4.10(d d, J=8.5$ and $5 \mathrm{~Hz})$ & $-\mathrm{CH}_{2}^{-}$ & - \\
\hline OH-5 & - & 12.93 & - & - \\
\hline $\mathrm{OH}-4^{\prime}$ & - & 9.62 & - & - \\
\hline
\end{tabular}

showed the molecular formula $\mathrm{C}_{21} \mathrm{H}_{20} \mathrm{O}_{10}$. Fourier Transform Infrared (FT-IR) spectra showed the wave number $v=3237 \mathrm{~cm}^{-1}$ indicated the presence of $\mathrm{OH}$ groups or aromatic carboxylic; $v=2930 \mathrm{~cm}^{-1}$ indicated the presence of alkane group, on $v=1741 \mathrm{~cm}^{-1}$ indicated ketone group $(\mathrm{C}=\mathrm{O})$, in $\mathrm{v}=1178 \mathrm{~cm}^{-1}$ indicated the presence of carboxylic groups or ester (COOH or COOR) and the $v=819 \mathrm{~cm}^{-1}$ indicated the presence of double bond or alkene group ( $\mathrm{R} 2 \mathrm{C}=\mathrm{CHR}$ ).

The elucidation of the structure of the isolated compound was further confirmed by NMR spectra consisting of ${ }^{1} \mathrm{H}-\mathrm{NMR},{ }^{13} \mathrm{C}-\mathrm{NMR}$, HSQC and HMBC. ${ }^{1} \mathrm{H}-\mathrm{NMR}$ spectrum gives the information about the number of protons, chemical and electronic environment of protons. ${ }^{3} \mathrm{H}-\mathrm{NMR}$, ${ }^{13} \mathrm{C}$-NMR and 2D NMR spectra confirmed that the compound was flavonoid-glucoside. Aromatic ring showed at $\delta 6.71(\mathrm{~J}=2 \mathrm{~Hz}, \mathrm{H}-6)$ and $\delta 6.72(J=2 \mathrm{~Hz}, \mathrm{H}-8)$. The two singlets at $\delta 12.9$ and 9.62 indicated two hydroxy groups and were located at the position of C-4'( $\delta$ 154.6) and C-5 ( $\delta$ 163.0), respectively. The position of the substituted groups were characterized by the presence of ${ }^{1} \mathrm{H}_{-}{ }^{13} \mathrm{C}$ correlations in the HMBC spectrum. The HMBC spectrum shows a correlation between the anomeric proton at $\delta 5.06$ with $\mathrm{C}-7$ ( $\delta$ 161.6) that indicated the position of the glucoside moiety. Based on the spectral data, the structure of the isolated compound was determined as apigenin-7-O- $\beta$-D-glucopiranoside (Figure 1).

Apigenin-7-O- $\beta$-D-glucopiranoside has known as apigetrin or cosmosiin. This compound was found in the Cosmos bipinnatus flower, Zinnia elegans and many other plants. Cosmosiin has an antiplatelet activity with $\mathrm{IC}_{50}$ of $0.18 \mathrm{mg} / \mathrm{mL}$. Cosmosiin also showed the anti-amoeba activity with $\mathrm{IC}_{50} 22.3 \mu \mathrm{g} / \mathrm{mL} .^{10}$ The other study showed that several flavonoid compounds that capable to inhibit HIV-1 RT enzyme. Xanthohumol,

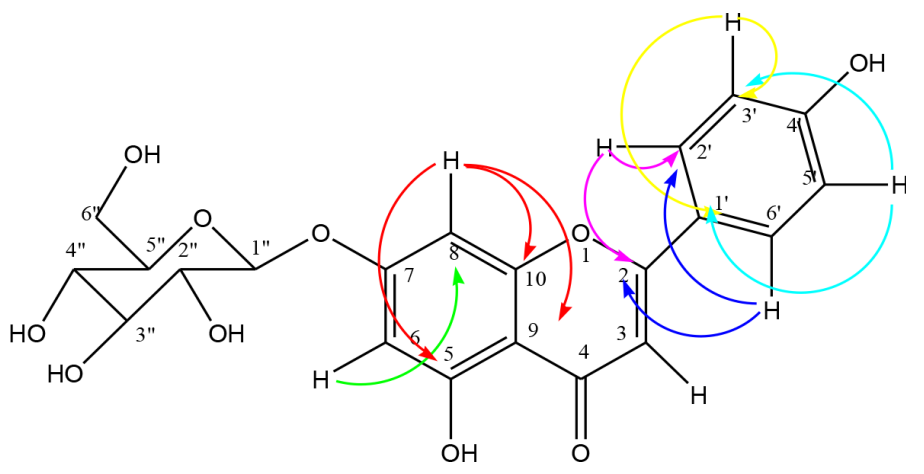

Figure 1: Chemical structure and $\mathrm{HMBC}$ correlation of isolate
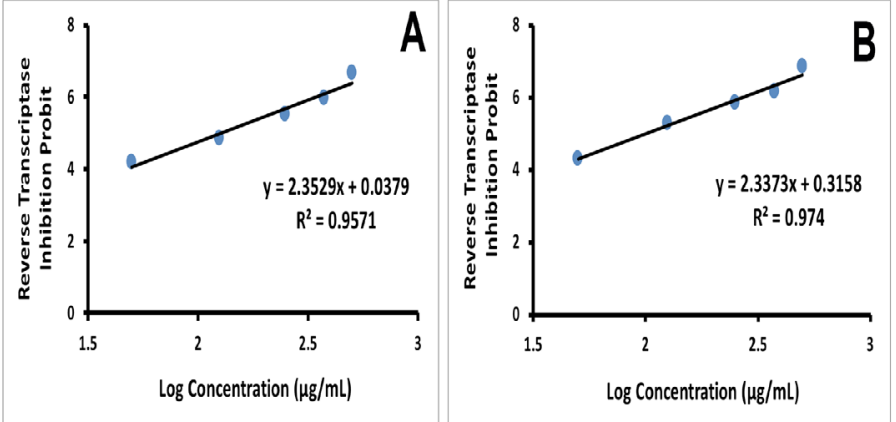

Figure 2: Reverse transcriptase inhibition curve by (A) lamivudine, and (B) isolate. 
prenylchalcone from Humulus lupulus are able to inhibit the replication of HIV-1 in PBMCs with $\mathrm{EC}_{50} 20.74 \mathrm{mg} / \mathrm{mL}^{.11}$ Vitex negundo L. ethanolic extract has inhibitory activity against HIV-1 RT of $92.8 \%$ at a concentration of $200 \mu \mathrm{g} / \mathrm{mL}$. The extract was analyzed using HPLC shown that it contains flavonoids such as rutin, luteolin, myricetin, quercetin, kaemferol, quercetagetin. ${ }^{12}$

In this study as standard was used lamivudine. Le et al. (2007) reported that lamivudine revealed HIV-1 RT inhibition activity with $\mathrm{IC}_{50}$ value of $6.5 \mu \mathrm{M} .{ }^{13}$ The isolated compound is flavonoid and showed strong anti-HIV activity. The result of this study supported anti HIV activity of flavonoid. ${ }^{14}$ Some phytochemicals such as tannins, gallotannins, ellagitannins, cyanidin, and flavonoids from Terminalia catappa were reported having anti-HIV activity. ${ }^{15}$ Ethanolic leaves extract of Vitex negundo demonstrated good HIV-1 Reverse Transcriptase activity of $92.8 \%$ at $200 \mathrm{mg} / \mathrm{ml}$. The extract contained flavonoid such as: kaemferol, myricetin, quercetin, quercetagetin, isorhamnetin and luteolin. ${ }^{12}$ Another study reported that flavanone and flavonol glycosides isolated from the leaves of Thevetia peruviana exhibited HIV-1 reverse transcriptase and HIV-1 integrase inhibitory activities. ${ }^{14}$ Flavonoid myricetin showed potential activity against HIV-1 in vitro microbicide activity model, and also showing insignificant cytotoxic effects. ${ }^{16}$ Luteolin and its derivates from Colues parvifolius exhibited inhibitory activities against HIV-1 IN. ${ }^{17}$

\section{CONCLUSION}

This research showed that the Erythrina variegata leaves extract were potential as HIV-1 RT inhibitor. The isolated compound was determined as apigenin-7-O- $\beta$-D-glucopiranoside or also known as apigetrin or cosmosiin. The isolate was also shown to be active against HIV-1 RT enzyme with $\mathrm{IC}_{50}$ of $100.59 \mu \mathrm{g} / \mathrm{mL}$.

\section{ACKNOWLEDGEMENT}

We acknowledge research supported by Riset Strategis Nasional No. 2219/ H2.R12/HKP.05.00/2014. We also thank to Faculty of Pharmacy, Universitas Indonesia for laboratory facilities to conduct this research.

\section{CONFLICT OF INTEREST}

The authors declare no conflict of interest.

\section{REFERENCES}

1. Djoerban Z, Djauzi S. HIV/AIDS Di Indonesia. in Buku Ajar IImu Penyakit Dalam
Jilid III Edisi IV. 4rd ed. Jakarta: FKUI; 2007.

2. UNAIDS. Global Report: UNAIDS Report on the Global AIDS Epidemic 2012.; 2012.

3. Spallarossa A, Cesarini S, Ranise A, Bruno O, Schenone S, La Colla P, et al. Novel modifications in the series of O-(2-phthalimidoethyl)-N-substituted thiocarbamates and their ring-opened congeners as non-nucleoside HIV-1 reverse transcriptase inhibitors. Eur J Med Chem. 2009;44(4):1650-63. doi:10.1016/j. ejmech.2008.09.024.

4. Han H, He W, Wang W, Gao B. Inhibitory effect of aqueous dandelion extract on HIV-1 replication and reverse transcriptase activity. BMC Complement Altern Med. 2011;11:112

5. Syahdi RR, Mun'im A, Suhartanto $H$, Yanuar A. Virtual screening of Indonesian herbal database as HIV-1 reverse transcriptase inhibitor. Bioinformation. 2012;8(24):1206-10. doi:10.6026/97320630081206.

6. Kumar A, Lingadurai S, Jain A, Barman NR. Erythrina variegate Linn: A review on morphology, phytochemistry, and pharmacological aspects. Pharmacogn Rev. 2010;4(8):147-52

7. Chin Y-W, Kinghorn AD. Structural characterization, biological effects, and synthetic studies on xanthones from mangosteen (Garcinia mangostana), a popular botanical dietary supplement. Mini Rev Org Chem. 2008;5:355-64.

8. Ahmad AR, Elya B, Mun'im A. Antioxidant activity and isolation of Xanthine Oxidase Inhibitor from Ruellia tuberosa L. leaves. Pharmacogn J. 2017;9(5):607-10.

9. Markham ØMAKR, ed. Flavonoids Chemistry, Biochemistry and Applications. CRC Taylor and Francis; 2006.

10. Cimanga RK, Kambu K, Tona L, Hermans N, Apers S, Totté J, et al. Cytotoxicity and in vitro susceptibility of Entamoeba histolityca to Morinda morindoides leaf extracts and its isolated constituents. J Ethnopharmacol. 2006;107(1):83-90.

11. Wang $\mathrm{Q}$, Ding ZH, Liu JK, Zheng YT. Xanthohumol, a novel anti-HIV-1 agent purified from Hops Humulus lupulus . Antivir Reasearch. 2004;64(3):189-94.

12. Kannan M, Rajendran P, Nair R. HIV-1 reverse transcriptase inhibition by Vitex negundo $L$. leaf extract and quantification of flavonoids in relation to anti-HIV activity. J Cell Mol Biol. 2012;10(2):53-9.

13. LiY, Mao S, Hager MW, Becnel KD, Schinazi RF, Liotta DC. Synthesis and Evaluation of 2'-Substituted Cyclobutyl Nucleosides and Nucleotides as Potential Anti-HIV Agents. Bioorganic Med Chem Lett 17. 2007;17:3398-401. doi:10.1016/j. bmcl.2007.03.094

14. Tewtrakul S, Nakamura N, Hattori M, Fujiwara T, Supavita T. Flavanone and flavonol glycosides from the leaves of Thevetia peruviana and their HIV-1 reverse transcriptase and HIV-1 integrase inhibitory activities. Chem Pharm Bull. 2002;50(5):630-5

15. Dwevedi A, Dwivedi R, SharmaYK. The. Exploration of phytochemicals found in Terminalia sp. and their antiretroviral activities. Pharmacogn Rev. 2016;10(20):78-83.

16. Pasetto S, Pardi V, Murata R. Anti-HIV-1 Activity of flavonoid Myricetin on HIV-1 infection in a dual-chamber. PLoS One. 2014;9(12):115-323.

17. Tewtrakul S, Miyashiro H, Nakamura N, Hattori M, Kawahata T, Otake T, et al. HIV-1 Integrase inhibitory substances from Coleus parvifolius. Phytotherapy Res. 2003;239:232-9. 